\title{
Immobilization of $\alpha$-Amylase Produced by Bacillus circulans GRS 313
}

\author{
Gargi Dey, Bhupinder Singh and Rintu Banerjee* \\ Microbial Biotechnology and Downstream Processing Laboratory; Agricultural and Food Engineering Department; \\ IIT-Kharagpur; 721302; India
}

\begin{abstract}
A maltooligosaccharide-forming amylase from B circulans GRS 313 was immobilized by entrapment in calcium alginate beads. The immobilized activity was affected by the size of the bead and bead size of $2 \mathrm{~mm}$ was found to be most effective for hydrolysis. Kinetics constants, $K_{m}$ and $V_{\text {max }}$ were estimated and were found to be affected by the bead size. The catalytic activity of the enzyme was studied in presence of various starchy residues and metal ions. $\mathrm{HgCl}_{2}, \mathrm{CuSO} 4$ and $\mathrm{FeCl}_{3}$ caused inhibition of the enzyme. The reaction conditions, pH and temperature, was optimized using response surface methodology. At the optimum $\mathrm{pH}$ and temperature of 4.9 and $57^{\circ} \mathrm{C}$, the apparent activity was 25.6U/g of beads, resulting in almost 2-fold increase in activity. The immobilized enzyme showed a high operational stability by retaining almost $85 \%$ of the initial activity after seventh use.
\end{abstract}

Keywords: Bacillus circulans GRS313; entrapment; maltooligosaccharide-forming amylase; response surface methodology; starchy residues

\section{INTRODUCTION}

The application of maltooligosaccharide-forming amylase in the baking industry is potentially very interesting. It has been reported that maltooligosaccharides stop bread firming and increase the shelf life of the baked products (Hebeda, 1990; Dziezak 1991; Okada and Nakakuki, 1992). For continuous production of maltooligosaccharides immobilized $\alpha$ amylase would have several advantages like easy recovery of the biocatalyst from the finished product, simplifying product purification process, providing opportunities for scaling-up and allowing the development of processes based different reactor configurations. A wide variety of carriers have been used for immobilization of amylase (Strumeyer 1974; Linko et al., 1975; Dumitrui et al., 1985; Emne'us et al., 1990; Zanin et al., 1994; Cong et al., 1995; Kurakake et al., 1997; Aksoy et al., 1998; Chen et al., 1998; Tanyolac et al., 1998; Tien and Chiang 1999). However, these covalent binding techniques involve chemical modification of the enzyme. It is preferable that the method employed for immobilization of enzyme should cause as little trauma to the enzyme as possible. Entrapment fulfills this criterion. Though entrapment is used mainly for immobilization of cells, in case of immobilized cells, it causes diffusional and permeability problems which might impair the uptake and transport of substrate as well as excretion of products. In addition to this, many other enzymes active in the whole cell might lead to unwanted side reactions. Thus, in the

\footnotetext{
* Author for correspondence
} 
present study an attempt was made to immobilize a maltooligosaccharide-forming amylase by entrapment as entrapping method leads to immobilized biocatalyst with high retention of specific activity.

Among the many matrices available, one of the most frequently used is entrapment within porous matrices, such as alginate often in the form of beads. This sort of system is reasonably safe, simple and cheap offering good mechanical strength. The present study deals with the immobilization of maltooligosaccharide-forming amylase by entrapment in calcium alginate beads. The conditions of entrapment like concentration of sodium alginate and bead size were optimized for highest apparent activity. The kinetics of the immobilized enzyme entrapped in different bead size was analyzed. The process parameters, $\mathrm{pH}$ and temperature, affecting the performance of the immobilized enzyme were optimized using response surface methodology. Lastly, the catalytic properties and reusability of the immobilized enzyme were studied.

\section{MATERIALS AND METHODS}

\section{Materials}

Sodium alginate, calcium chloride and soluble starch were obtained from E Merck, and dinitrosalicylic acid (DNS) was purchased from Lancaster, England. All the other chemicals used were of analytical grade.

\section{Enzyme immobilization}

Enzyme was prepared from Bacillus circulans GRS 313 cultivated at $40^{\circ} \mathrm{C}$ with an initial $\mathrm{pH}$ of 5.5 for $48 \mathrm{hrs}$ in a medium described previously (Dey et al., 2000). An equal volume of enzyme solution and sodium alginate solution was mixed to give a $4 \%(\mathrm{w} / \mathrm{v})$ final concentration of sodium alginate solution in the mixture. The mixture obtained was extruded dropwise through a pastuer pipette $(1 \mathrm{~mm}$ diameter) into a gently stirred $2 \%$ (w/v) $\mathrm{CaCl}_{2} \cdot 2 \mathrm{H}_{2} \mathrm{O}$ solution for $2 \mathrm{~h}$ to give bead size of $3 \mathrm{~mm}$. The calcium alginate beads containing the enzyme were thoroughly washed with distilled water and used for further studies. Beads of different sizes $5 \mathrm{~mm}, 4 \mathrm{~mm}$ and $2 \mathrm{~mm}$ were made by using pastuer pipettes of diameter $3 \mathrm{~mm}$, $2 \mathrm{~mm}$ and $70 \mu \mathrm{m}$ respectively.
Immobilized enzyme assay

The reaction mixture, containing $20 \mathrm{ml}$ of $2 \%$ (w/v) starch solution in acetate buffers $(0.1 \mathrm{M}, \mathrm{pH}$ 4.5) and $2 \mathrm{~g}$ of calcium alginate beads were incubated at $50^{\circ} \mathrm{C}$ in a waterbath shaker. After the enzymatic reaction had proceeded for $10 \mathrm{~min}, 0.5$ $\mathrm{ml}$ of the digested products was assayed for amylase activity using DNS according to Bernfeld method (1955). One unit was defined as the amount of amylase that produced $1 \mu$ mole of reducing sugar under assay condition per gram of bead.

\section{Determination of immobilization efficiency}

Immobilization efficiency was determined from the difference in enzyme activity in the solution before and after the immobilization.

Immobilization yield $(\%)=(\mathrm{I} / \mathrm{A}-\mathrm{B}) \times 100$

where $\mathrm{A}=$ added enzyme $(\mathrm{U} / \mathrm{g}$ of bead $) ; \mathrm{B}=$ unbound enzyme (U/g of bead);

$\mathrm{I}=$ immobilized enzyme (U/g of bead).

\section{Optimization of curing time of calcium alginate} beads

The calcium alginate beads were cured in $2 \%$ $(\mathrm{w} / \mathrm{v})$ calcium alginate solution for different time intervals of $30,60,90,120,150$ and $180 \mathrm{~min}$. After curing, the beads were washed thoroughly with distilled water, wiped dry and their hardness was measured using a Texture- analyzer (StevensLFRA), L6512. The hardness of the beads was expressed as the load ( $\mathrm{g}$ force) that the beads could withstand for 1 milimeter compression.

\section{Determination of kinetic constants}

Kinetic experiments were carried out at $50^{\circ} \mathrm{C}$ in $0.1 \mathrm{M}$ acetate buffer $\mathrm{pH} 4.5$ at different substrate concentrations. The kinetic constants $\mathrm{K}_{\mathrm{m}}$ and $\mathrm{V}_{\max }$ were calculated according to Lineweaver-Burk plot.

Optimization of amount of enzyme-immobilized beads in the reaction medium

Amylase activity with respect to amount of immobilized beads in the reaction media was studied by taking different weights of immobilized beads starting from 1-6g along with the substrate at $\mathrm{pH} 4.5$ and temperature of $50^{\circ} \mathrm{C}$.

Optimization of process conditions using response surface methodology (RSM)

RSM was used to optimize the reaction conditions with reference to immobilized amylase activity. 
The experimental design was a central composite experimental plan (Box et al., 1957; Khuri and Cornell, 1987) with two factors: temperature of the reaction $\left(\mathrm{X}_{1}\right)$ and $\mathrm{pH}$ of the reaction medium $\left(\mathrm{X}_{2}\right)$ at five levels of $-\sqrt{ } 2,-1,0,1, \sqrt{ } 2$. Preliminary trials enabled us to fix the range of the $\mathrm{pH}$ from 4.0 to 4.9 and the temperature from $43^{\circ} \mathrm{C}$ to $57^{\circ} \mathrm{C}$. The variable levels $\mathrm{X}_{\mathrm{i}}$ were coded as $\mathrm{X}_{\mathrm{i}}$ according to the following equation such that $X_{o}$ corresponded to the central value:

$$
\mathrm{X}_{\mathrm{i}}=\left(\mathrm{X}_{\mathrm{i}}-\mathrm{X}_{0}\right) / \Delta \mathrm{X}_{\mathrm{i}}, \mathrm{i}=1,2,3, \ldots \mathrm{k}
$$

where $x_{i}$ is the dimensionless value of an independent variable; $X_{i}$ is the real value of an independent variable; $\mathrm{X}_{0}$ is the real value of an independent variable at the center point.

$\Delta \mathrm{X}_{\mathrm{i}}$ is the step change. In this study the rotatable experimental plan consisted of 12 trials. The results were modeled using a second order polynomial equation:

$$
\mathrm{Y}_{\mathrm{i}}=\beta_{\mathrm{o}}+\Sigma \beta_{\mathrm{i}} \mathrm{x}_{\mathrm{i}}+\Sigma \beta_{\mathrm{ii}} \mathrm{x}_{\mathrm{i}}^{2}+\Sigma \beta_{\mathrm{ij}} \mathrm{x}_{\mathrm{i}} \mathrm{x}_{\mathrm{j}}
$$

where $Y_{i}$ is the activity of the immobilized enzyme which is regarded the predicted response; $\mathrm{x}_{\mathrm{i}} \mathrm{X}_{\mathrm{j}}$ are input variables which influence the response variable $Y ; \beta_{0}$ is the offset term; $\beta_{\mathrm{i}}$ is the ith linear coefficient; $\beta_{\mathrm{ii}}$ is the ith quadratic coefficient and $\beta_{\mathrm{ij}}$ is ijth interaction coefficient.

The value of the dependent response was the mean of two replications. The second order polynomial coefficients were calculated using the MATLAB software (version 4, The Math Works Inc., MA, USA.). The results were analyzed using SYSTAT (8.0, HSS Inc. USA), a statistical package. Statistical analysis of the model was performed to evaluate the analysis of variance (ANOVA), Fisher's F-test (overall model significance), its associated probability $\mathrm{p}(\mathrm{F})$ and the Student's tvalue for the estimated coefficients and the associated probabilities $\mathrm{p}(\mathrm{t})$. The results were represented as contour plots (2 D) using MATLAB software (version 4, The Math Works Inc., MA, USA.).
Properties of immobilized enzyme

Rate of hydrolysis of natural substrates

A $2 \%$ (w/v) solution of different starchy substrates viz., wheat flour, barley, arrowroot, sago and soluble starch were incubated with immobilized enzyme beads at $57^{\circ} \mathrm{C} .0 .5 \mathrm{ml}$ of the digested products was assayed for amylase activity after regular time intervals.

\section{Effect of metal ions on activity of the enzyme}

To study the effect of various metal ions on the activity of immobilized amylase, the following compounds were added individually in the enzyme assay: $\mathrm{CaCl}_{2}, \mathrm{BaCl}_{2}, \mathrm{CoCl}_{2}, \mathrm{FeCl}_{3}, \mathrm{NaCl}, \mathrm{HgCl}_{2}$ and $\mathrm{CuSO}_{4}$.

\section{Operational stability of the immobilized amylase}

After each amylase activity assay of the beads, they were removed, washed thoroughly with distilled water and stored at $4^{\circ} \mathrm{C}$. Then the beads were reassayed for amylase activity and the same process was repeated till the seventh use.

\section{RESULTS AND DISCUSSION}

\section{Optimization of parameters for immobilization on alginate gel}

\section{a) Effect of sodium alginate concentration}

It has been reported that the porosity of the calcium alginate beads depend upon the alginate type and the gelling agent concentration (Longo et al., 1992). So various concentrations of sodium alginate solution was used for preparation of calcium alginate beads in order to vary the relative degree of crosslinking, which would create different pore size. The immobilization efficiency was found to be highest $(75 \%)$ for a final concentration of $4 \%(\mathrm{w} / \mathrm{v})$ sodium alginate solution (Fig. 1).

Higher immobilization efficiency could not be attained due to some leakage of the enzyme into the solution. Although, in practice reducing the size of the pores can reduce leakage, some initial leakage of the enzyme molecule is certain to occur (Zaborsky, 1973). The lower immobilization efficiency in case of lower percentage sodium alginate solution might be due to larger pore size and consequently greater leakage of the enzyme from the matrix. 


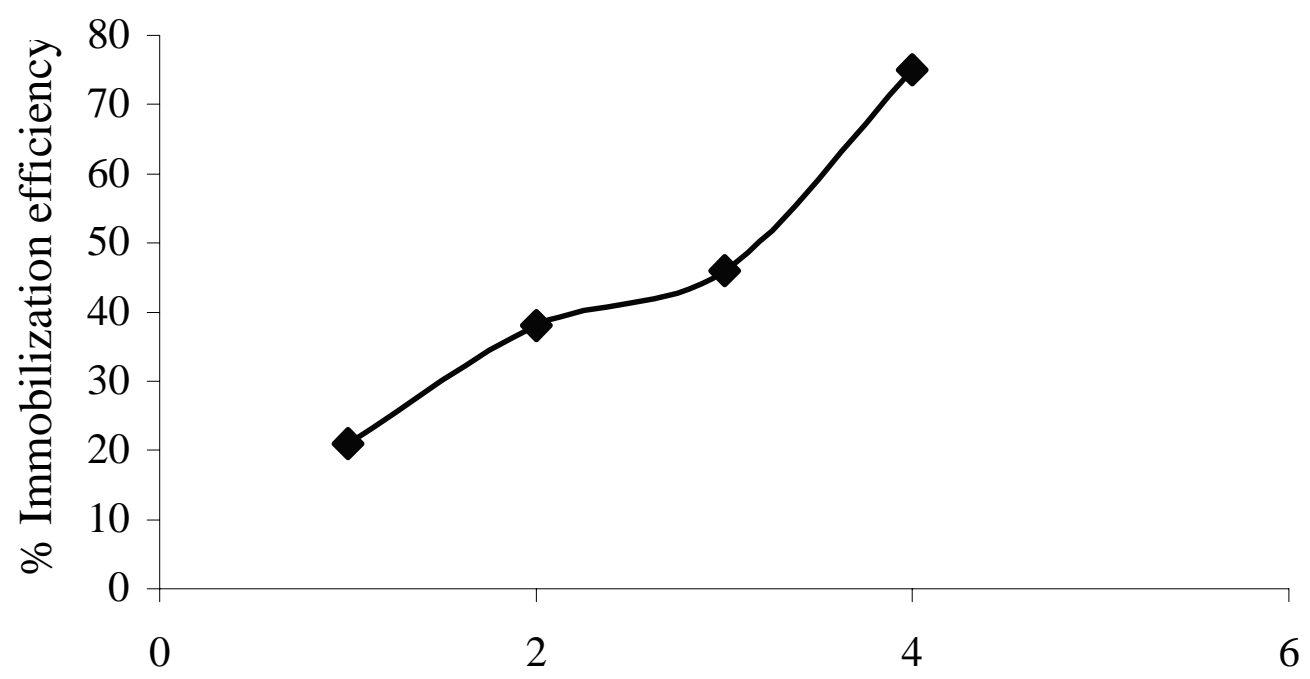

Concentration of sodium alginate $(\mathrm{g} \%, \mathrm{w} / \mathrm{v})$

Figure 1 - Effect of alginate concentration on immobilization efficiency

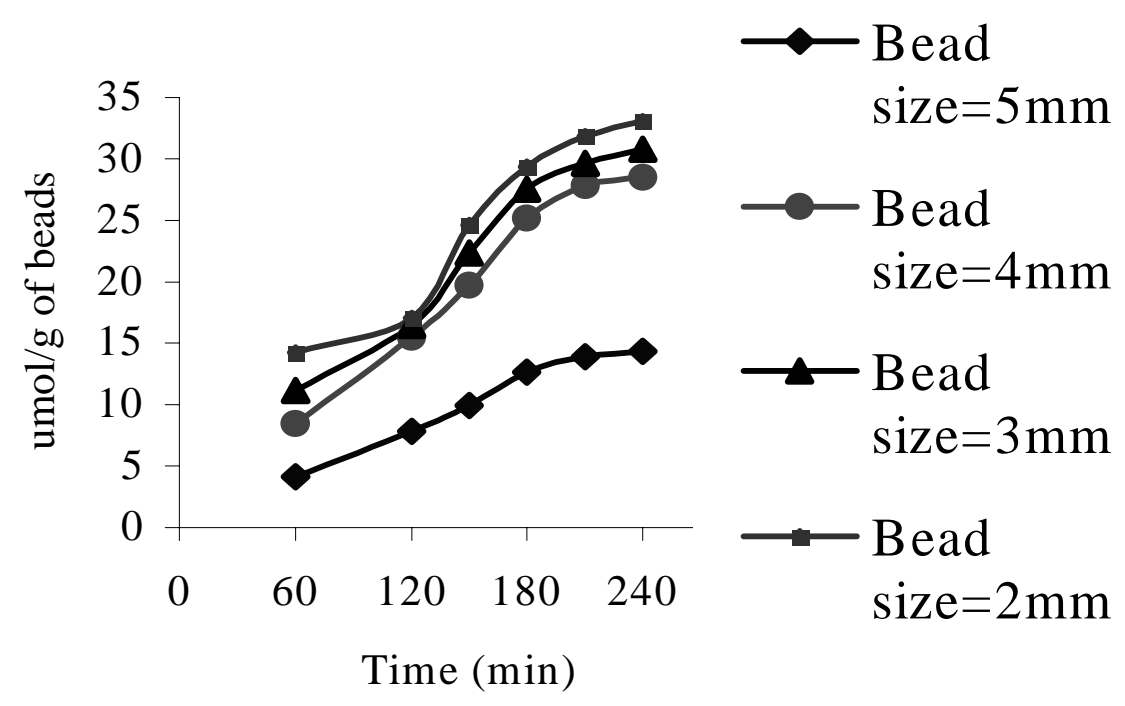

Figure 2 - Effect of bead size on rate of starch hydrolysis 
b) Effect of curing time of calcium alginate beads Time required for the gel to set is an important step in immobilization as it affects the stability of the resulting calcium alginate beads. The effect of curing time on the hardness of the calcium alginate beads was evaluated. The treatment of the beads in a calcium chloride bath for $2 \mathrm{hrs}$ gave a hardness of $85 \mathrm{~g}$ (Table 1). Prolonged curing of the beads with calcium chloride solution did not improve the structural stability of the beads.

Table 1 - Effect of curing time on structural stability of the beads

\begin{tabular}{cc}
\hline $\begin{array}{c}\text { Curing Time } \\
(\mathbf{m i n})\end{array}$ & $\begin{array}{c}\text { Bead Heardness } \\
(\mathbf{g})\end{array}$ \\
\hline 30 & 48 \\
60 & 55 \\
90 & 67 \\
120 & 85 \\
150 & 84 \\
180 & 85 \\
\hline
\end{tabular}

Optimum conditions for using amylaseimmobilized beads

\section{a) Bead size}

In the immobilized enzyme system, as the substrate has to diffuse for the enzymatic reaction to take place, the size of the final lattice (bead) has significant effect on the rate of hydrolysis. Moreover, the bead size determines the suitability for reactor configuration. In situations where the substrate has to be transported from the bulk solution to the outer surface of the matrix, both the intraparticular diffusion and the external mass transfer should be taken into consideration. However, in the present study, the external transport has not been considered on the assumption that greater contribution is from the intraparticle mass transfer. As shown in Fig. 2, the highest rate of starch hydrolysis was observed with bead size of $2 \mathrm{~mm}$ and the bigger sizes showed lower rate. From the above finding it may be concluded that the beads of $2 \mathrm{~mm}$ offered lesser diffusion resistance compared to the larger beads.

\section{Kinetic analysis}

Lineweaver-Burk plots were used for estimation of the kinetic constants, $V_{\max }$ and $\mathrm{K}_{\mathrm{m}}$ for different sizes of beads. According to the tabulated results (Table 2), $\mathrm{K}_{\mathrm{m}}$ of the immobilized amylase increased with the size of the beads. The results obtained in the present study were similar to those reported for immobilized glucoamylase (Cabral, 1982). Koji et al. (1999) also observed that the $K_{m}$ for the immobilized urease became higher with increasing the fiber diameter for entrapmentimmobilized urease. In the present study, the internal diffusion effects are present in the operational conditions used and as the beads of larger size offer more internal diffusion resistance, the $K_{m}$ value increases with the size of the bead. Concomitantly, as the diffusional limitations were eliminated by reducing the size, the maximal activity, $\mathrm{V}_{\max }$, increased with the decrease in the size of the beads.

Table 2 - Kinetic constants of enzyme

\begin{tabular}{|c|c|c|}
\hline Bead size & $\begin{array}{c}\mathrm{K}_{\mathrm{m}} \\
(\mathrm{mg} / \mathrm{ml})\end{array}$ & $\begin{array}{c}\mathbf{V}_{\max } \\
(\mu \mathrm{mol} / \mathrm{ml})\end{array}$ \\
\hline $4 \mathrm{~mm}$ & 31.2 & 30.03 \\
\hline $3 \mathrm{~mm}$ & 28.2 & 33.08 \\
\hline $2 \mathrm{~mm}$ & 23.75 & 36.23 \\
\hline
\end{tabular}

For practical application, an immobilized system with lower $K_{m}$ value and faster rate of reaction is preferred. In this respect, immobilized enzyme particle of $2 \mathrm{~mm}$ size gave satisfactory results and was used for further investigations.

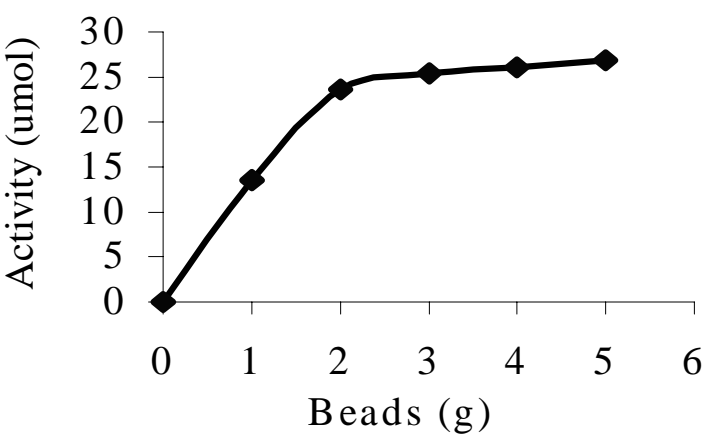

Figure 3 - Effect of amount of enzyme on activity of enzyme

\section{b) Amount of beads}

Different amounts of amylase-immobilized beads were introduced into the reaction medium and degree of catalysis was assayed. The rate of hydrolysis increased with the increase in amount 
of immobilized catalyst and maximum activity was realized with $2 \mathrm{~g}$ of beads (Fig. 3). However, further increase in the amount of beads did not increase the hydrolysis rate.

\section{c) Reaction temperature and $\mathrm{pH}$ optimization by RSM}

Response surface methodology allows the verification of the effects of the variables individually and their interaction. This is a statistical model that correlates the variables and permits the optimization of the hydrolysis process. The experimental design for the various treatments was based on preliminary work, which established that an optimum could be found within the range of parameters studied. The summary of the Central Composite Experimental Design (CCD) for optimization of the reaction $\mathrm{pH}$ and temperature has been given in Table 3 .

Table 3 - Two factored central composite experimental design. The numbers in parenthesis are the coded values of the variable.

\begin{tabular}{ccc}
\hline Run & $\mathbf{X}_{\mathbf{1}}$ & $\mathbf{X}_{\mathbf{2}}$ \\
\hline 1 & $55(1)$ & $4.2(-1)$ \\
2 & $55(1)$ & $4.8(1)$ \\
3 & $45(-1)$ & $4.2(-1)$ \\
4 & $45(-1)$ & $4.8(1)$ \\
5 & $50(0)$ & $4.5(0)$ \\
6 & $50(0)$ & $4.5(0)$ \\
7 & $50(0)$ & $4.9(\sqrt{ } 2)$ \\
8 & $50(0)$ & $4.07(-\sqrt{ } 2)$ \\
9 & $57(\sqrt{ } 2)$ & $4.5(0)$ \\
10 & $43(-\sqrt{ } 2)$ & $4.5(0)$ \\
11 & $50(0)$ & $4.5(0)$ \\
12 & $50(0)$ & $4.5(0)$ \\
\hline
\end{tabular}

The results of the experiments were analyzed by multiple regression procedure and the following model, relating the amylase activity with the independent process variables, temperature $\left(\mathrm{X}_{1}\right)$ and $\mathrm{pH}\left(\mathrm{X}_{2}\right)$, was fitted:

$\mathrm{Y}=427.9141-5.5101 \mathrm{X}_{1}-139.622 \mathrm{X}_{2}-0.0224 \mathrm{X}_{1}^{2}$ $+6.9477 \mathrm{X}_{2}^{2}+1.7967 \mathrm{X}_{1} \mathrm{X}_{2}$

The fit of the regression equation was expressed by evaluation of the multiple correlation coefficient, $\mathrm{R}$, and the determination coefficient, $\mathrm{R}^{2}$. The coefficient of determination, $\mathrm{R}^{2}$ was found to be 0.984 , indicating that the sample variation of $98.4 \%$ can be explained by the model. The value of $\mathrm{R}$ for immobilized amylase activity was 0.968 , showing a good agreement between experimental and predicted values. The corresponding analysis of variance (ANOVA) has been summarized in Table 4 . The $F$ value is a measure of the variation of the data about the mean. Generally, the calculated $\mathrm{F}$ value should be several times greater than the tabulated value if the model is a good prediction of the experimental results.

Table 4 - ANOVA

\begin{tabular}{cccccc}
\hline Source & DF & SS & MS & F value & p >F \\
\hline Blocks & 1 & 0.0096 & 0.0096 & & \\
Model & 5 & 352.48 & 70.496 & 325.77 & 0.00 \\
Error & 5 & 1.082 & 0.2164 & & \\
Total & 11 & 353.576 & 32.143 & & \\
\hline
\end{tabular}

Here the computed F-value was greater than the tabulated F-value, $\mathrm{F}_{5,5}=5.05$ at $\alpha=0.05$ level. From the high $\mathrm{F}$ value and a very low probability $(\mathrm{p}>\mathrm{F}=0.000)$ it can be concluded that the model was a good prediction of the experimental results. The Student t-distribution and the corresponding p-values along with the second order polynomial coefficients were evaluated using SYSTAT (8.0, HSS Inc. USA) (Table 5).

Table 5 - Coefficients of the model

\begin{tabular}{ccccc}
\hline \multicolumn{2}{c}{$\begin{array}{c}\text { Co } \\
\text { eff }\end{array}$} & $\begin{array}{c}\text { Standard } \\
\text { error }\end{array}$ & t value & p value \\
\hline Intercept & 427.914 & 125.44 & 3.411 & 0.014 \\
$\mathrm{X}_{1}$ & -5.51 & 2.121 & -2.598 & 0.041 \\
$\mathrm{X}_{2}$ & -139.622 & 42.453 & -3.289 & 0.017 \\
$\mathrm{X}_{1}{ }^{2}$ & -0.022 & 0.015 & -1.45 & 0.197 \\
$\mathrm{X}_{2}{ }^{2}$ & 6.948 & 4.372 & 1.589 & 0.163 \\
$\mathrm{X}_{1} \mathrm{X}_{2}$ & 1.797 & 0.322 & 5.579 & 0.001 \\
\hline
\end{tabular}

The p-value serves as a tool for checking the significance of each of the coefficients. It is evident from the $\mathrm{p}$ value $(0.001)$ that interactive effect between $\mathrm{pH}$ and temperature most significantly influenced the immobilized amylase activity. The contour plot (Fig. 4), depicting the effect of $\mathrm{pH}$ and temperature on amylase activity, clearly showed an optimum in the boundaries. The optimum point was evaluated using gradient method in the direction of steepest ascent. Since the optimum was obtained at the boundary, it is possible that the real optimum lies beyond the experimental range considered in the present study. 


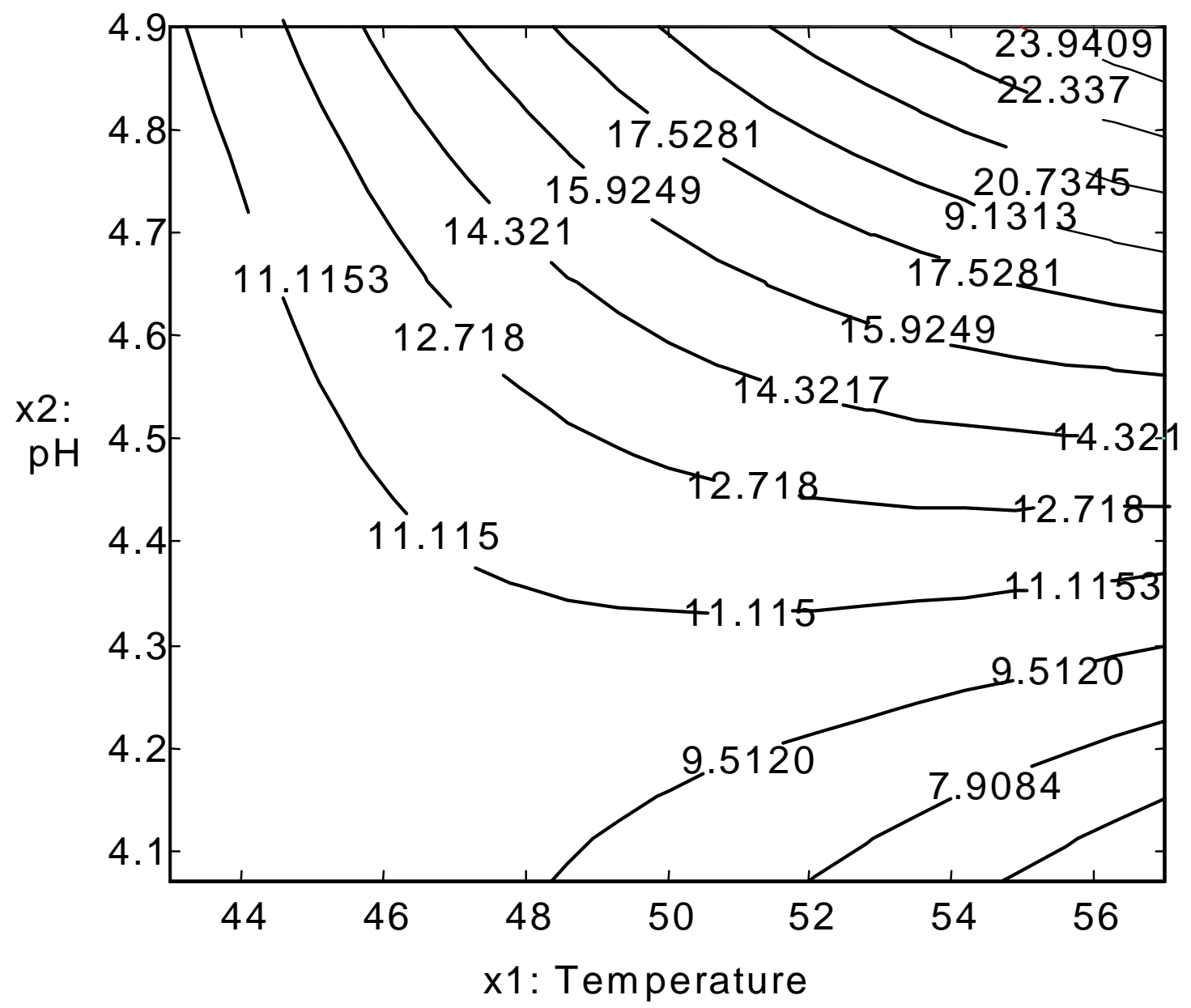

Figure 4 - Contour plot: effect of $\mathrm{pH}$ and temperature on amylase activity

Experiments were performed beyond the experimental range to confirm the present optimum points.

The optimum $\mathrm{pH}$ and temperature as evaluated from the plot were 4.9 and $57^{\circ} \mathrm{C}$ respectively. Thus the operating temperature of the immobilized matrix was raised from $50^{\circ} \mathrm{C}$ to $57^{\circ} \mathrm{C}$. It has been reported that only at an elevated temperature of $60^{\circ} \mathrm{C}$ complete degradation of starch to glucose can be achieved in the immobilized $\alpha$ amylase reactor (Emne'us et al., 1990). Hence the present immobilized system could have potential application not only for maltooligosaccharide production but also for production of glucose syrups. The enzyme activity was enhanced 2 folds, from $13 \mathrm{U} / \mathrm{g}$ of beads to $25.6 \mathrm{U} / \mathrm{g}$ of beads, after optimizing the process parameters using RSM. The reaction parameters, $\mathrm{pH}$ and temperature, for
Bacillus sp. $\alpha$-amylase covalently bonded to zirconium dynamic membrane, was optimized employing response RSM (Tien et al., 1999). They found an optimum $\mathrm{pH}$ and temperature 5.5 and $41^{\circ} \mathrm{C}$, respectively and the highest specific activity was $21.85 \mathrm{U} / \mathrm{mg}$. The higher temperature profile observed in case of amylase from Bacillus circulans may be because of some conformational effects due to entrapment, which protects the enzyme against heat denaturation. Response surface methodology has been used to optimize various reaction parameters of such enzyme catalyzed reactions. For instance, the esterification reaction between stearic acid and lactic acid using Rhizomucor miehei lipase and porcine pancreas lipase was optimized for maximum esterification using response surface methodology (Karanth and Divakar, 1999). 
Similarly, lipase catalyzed hydrolysis of methyloleate was optimized by RSM (Murthy et al., 2000).

Catalytic properties of the immobilized enzyme

a) Activation energy of the immobilized enzyme The logarithm of enzyme activity was plotted as a function of inverse of temperature and the activation energy was calculated from the Arrhenius equation (Fig. 5). The $\mathrm{E}_{\mathrm{a}}$ of the immobilized enzyme was found to be 5.7 $\mathrm{kcal} / \mathrm{mole}$.

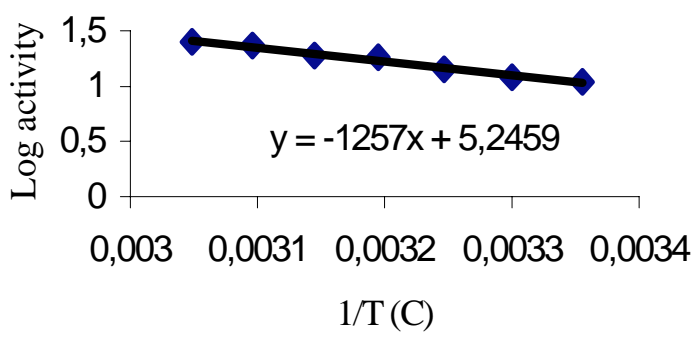

Figure 5 - Arrhenius plot

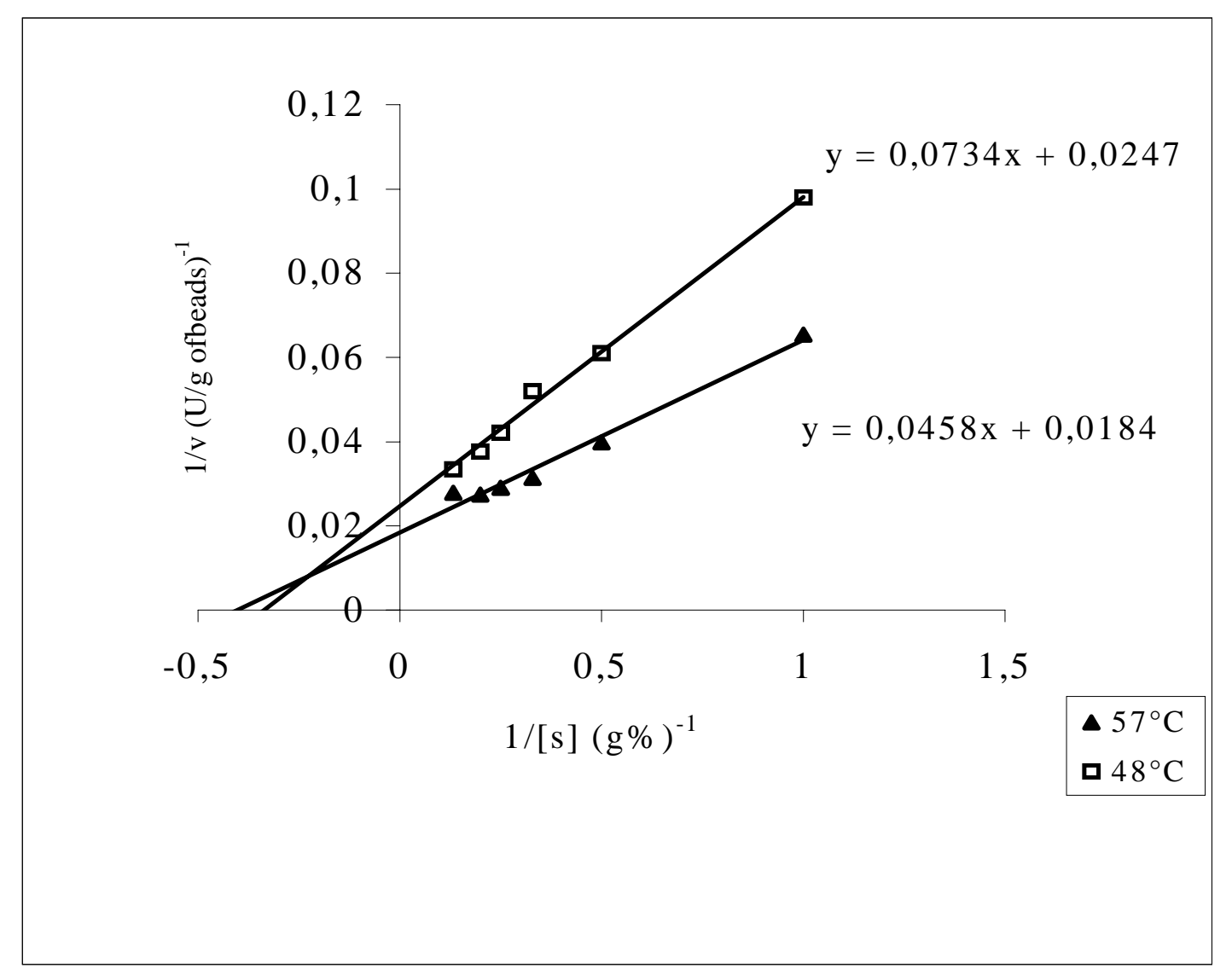

Figure 6 - Lineweaver-Burk plot

b) Kinetic constants of the enzyme

In order to make a rational reactor design for immobilized enzyme system it is important as well as necessary to evaluate the kinetics of the system for properties of immobilized enzyme. The kinetic constants, $K_{m}$, and $V_{\max }$ of the enzyme entrapped in $2 \mathrm{~mm}$ size bead was evaluated at $57^{\circ} \mathrm{C}$ and $50^{\circ} \mathrm{C}$ using Lineweaver-Burk plot (Fig. 6). The estimated $K_{m}$, at $57^{\circ} \mathrm{C}$ was found to be $26.5 \mathrm{mg} / \mathrm{ml}$ and that at $50^{\circ} \mathrm{C}$ was $29.71 \mathrm{mg} / \mathrm{ml}$. However, with the increase in temperature, $V_{\max }$ decreased from $56.5 \mathrm{U} / \mathrm{g}$ of bead to $40.48 \mathrm{U} / \mathrm{g}$ of beads.

c) Rate of hydrolysis of natural substrates

The substrate specificity of the $B$ circulans GRS313 amylase immobilized on natural hydrogel 
( $2 \mathrm{~mm}$ bead size) was tested on various substrates and results are shown in Fig. 7. The immobilized catalyst exhibited an appreciable hydrolytic capability in presence of starchy residues like wheat flour, sago, barley and arrowroot starch, which was comparable to soluble starch.

It may be inferred that the present entrapment system did not pose any diffusional limitations in case of these starchy residues to impair their effective hydrolysis by the immobilized enzyme.

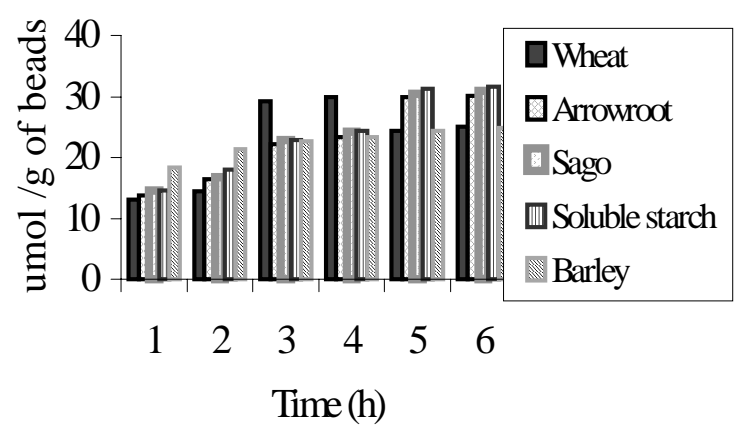

Figure 7 - Rate of hydrolysis in presence of different starchy substartes

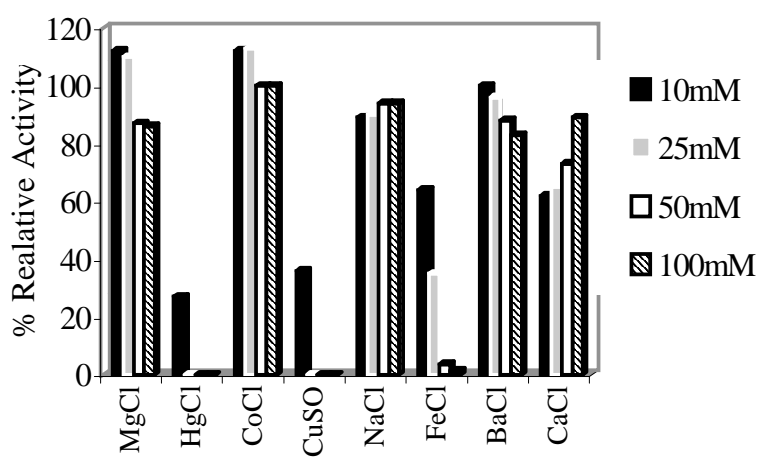

Figure 8 - Effect of salts on immobilized enzyme activity

\section{e) Operational stability}

The operational stability of immobilized enzymes is one of the most important factors affecting the utilization of an immobilized enzyme system. The operational stability of the maltooligosaccharide- forming amylase from $B$ circulans GRS 313 was evaluated in batch process. The results (Fig. 9) indicated that on repeated use of the immobilized amylase, $83 \%$ of the initial activity was retained upto seven cycles. After seventh cycle, there was loss of enzyme activity, which may be due to enzyme denaturation and due to physical loss of enzyme from the carrier. The enzyme in the present study is operationally more stable than the $\alpha$ amylase immobilized on nitrocellulose membrane which retained only $65 \%$ of the initial activity after seven runs (Tanyolac et al., 1998).

\section{d) Effect of metal ions on activity of the enzyme}

Among the various metal ions studied, apparent activity of the immobilized enzyme was increased by $112 \%$ and $113 \%$ in presence of $\mathrm{MgCl}_{2}$ and $\mathrm{CoCl}_{2}$ respectively (Fig. 8). $\mathrm{HgCl}_{2}, \mathrm{CuSO}_{4}$ and $\mathrm{FeCl}_{3}$ caused total inhibition of enzyme activity at $25 \mathrm{mM}$ concentrations. At a lower concentration of $10 \mathrm{mM}, \mathrm{HgCl}_{2}$ exhibited greatest degree of inhibition showing only $27 \%$ of relative activity.

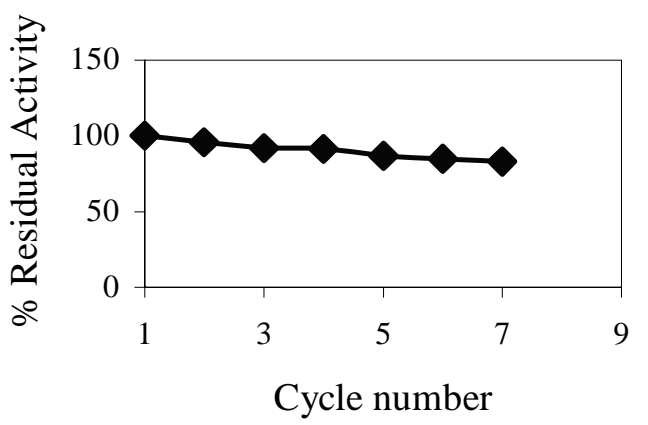

Figure 9 - Operational stability of immobilized amylase

\section{RESUMO}

Um maltooligossacarideo obtido a partir de amilase produzida por B. circulans GRS 313 foi imobilizada em alginato de sódio. A atividade enzimática foi afetada pelo tamanho da partícula. Partículas com $2 \mathrm{~mm}$ foram as mais efetivas na hidrólise. Constantes cinética $\mathrm{Km}$ e Vmax foram estimadas e afetadas pelo tamanho das partículas. A atividade catalítica da enzima foi estuda na presença de diferentes tipos de amido e íons metálicos. $\mathrm{HgCl} 2$, 
$\mathrm{CuSO} 4$ e $\mathrm{FeCl} 3$ provocaram inibição na enzima. As condições de reação (temperatura e $\mathrm{pH}$ ) foram otimizadas utilizando a metodologia da superfície de resposta. Em pH ótimo de 4,9 e temperatura de $57{ }^{\circ} \mathrm{C}$, a atividade aparente foi de $25.6 \mathrm{U} / \mathrm{g}$ de partículas, resultando num acréscimo de mais de 2 vezes na atividade da enzima. A imobilização da enzima mostrou uma alta estabilidade operacional pela retenção de $85 \%$ de sua atividade inicial após sete ciclos de utilização.

\section{ACKNOWLEDGEMENT}

The authors are grateful to Council for Scientific and Industrial Research (CSIR) for the fellowship of Ms Gargi Dey.

\section{REFERENCES}

Aksoy, S., Tumturk, H and Hasirci, N. (1998), Stability of alpha-amylase immobilized on poly (methyl methacrylate-acrylic acid) microspheres. J Biotechnol., 60, 37-46.

Bernfeld, P. (1955), Amylases, alpha and beta. In: Colowick, S. P. and Kaplan, N. O (eds.). Methods in enzymology. New York: Academic Press. v. 1. pp. 149-158.

Box, G. E. P. and Hunter, J. S. (1957), Multifactor experimental design for exploring response surfaces, Ann Math Statist., 28, 195-241.

Cabral, J. M. S. (1982), PhD Thesis, Technical University of Lisbon, Portugal.

Chen, Jyh-Ping; Sun, Yi-Ming and Chu, Ding-Hsin (1998), Immobilization of alpha -amylase to a composite temperature-sensitive membrane for starch hydrolysis. Biotechnol Prog., 14, 473-478.

Cong, L.; Kaul, R.; Dissing, U. and Mattiasson, B. (1995), A modem study on eurogit and polyethyleneimine as soluble carriers of $\alpha$-amylase for repeated hydrolysis of starch. J Biotechnol., 42, 75-84.

Dey, G., Banerjee, R. and Maiti, B. R. (2000), Thermostable maltooligosaccharide-forming amylase from Bacillus circulans GRS 313, Paper presented in National symposium on basic and applied aspects of plant and microbial biotechnology, 4-5 May, Pune, India.

Dumitriu, S. and Popa, M. (1985), Bioactive polymers 29. Immobilization of $\alpha$-amylase on Biozan-R. Br. Polym. J., 17, 56-59.

Dziezak, J. D. (1991), Enzymes: Catalyst for food process. Food Technol., 45, 78-85.

Emne'us, J. and Gorton, L. (1990), Effects on the hydrolysis of native starch and glycogen by a thermostable $\alpha$-amylase after immobilization on solid supports. Anal. Chim. Acta., 234, 97-106.
Hebeda, R. E.; Kinda, K. B. and Teague, W. M. (1990), Developments in enzymes for retarding staling of baked goods. Cereal Foods World., 35, 453-457.

Karanth, K. and Divakar, S. (1999), Preparation of stearoyl lactic acid ester catalyzed by lipases from Rhizomucor miehei and porcine pancreas optimization using response surface methodology, Appl. Microbiol. Biotechnol., 52, 579-584.

Khuri, A. I. and Cornell, J. A. (1987), Response surfaces: Design and analysis, In: Owen, D. B.; Cornell, R. G.; Kshirsagar, A. M.; Kennedy, W. J. and Shilling, E. G. (eds.). Statistics: textbooks and monographs. New York : Marcel Dekkar. v. 81. pp. 3-6.

Koji, N.; Koji, T.; Fumio, S. and Youichi, K. (1999), Entrap-immobilization of urease on composite gel fiber of cellulose acetate and zirconia. J. Soc. Fiber Science Technol., 55, 563-568.

Kurakake, M.; Ueki, M.; Hashimoto, S. and Komaki, T. (1997), Adsorption of $\alpha$-amylase on dextrin immobilized on kieselguhr or chitin. Carbohyd Polym., 34, 54-59.

Linko, Y. Y.; Saarinen, P and Linko, M. (1975), Starch conversion by soluble and immobilized $\alpha$-amylase. Biotechnol. Bioeng., 17, 153-159

Longo, M. A.; Novella, I. S.; Garcia L. A and Diaz, M. (1992), Diffusion of proteases in calcium alginate beads. Enzyme Microb. Technol., 14, 586-590.

Murthy, M. S. R. C.; Swaminathan, T. and Rakshit, Y. K. (2000), Statistical optimization of lipase catalyzed hydrolysis of methyloleate by response surface methodology. Bioproc. Engg., 22, 35-39.

Okada, M and Nakakuki, T. (1992), Oligosaccharides: Production, properties and applications. In: Schenck, F. W. (ed.). Starch Hydrolysis Products. New York: VHC Publishers. pp. 335-366.

Strumeyer, D. H.; Constantinides, A. and Freudenberger, J. (1974), Preparation and characterization of $\alpha$-amylase immobilized on collagen memebranes. J. Food Sci., 39, 498-502.

Tanyolac, D.; Yuruksoy, B. I. and Ozdural, A. R. (1998), Immobilization of a thermostable $\alpha$-amylase, Termamyl $^{\circledR}$, onto nitrocellulose membrane by cibacron blue F3GA dye binding. Biochem. Engg. J., 2, 179-186.

Tien, C. J. and Chiang, B. H. (1999), Immobilization of $\alpha$-amylase on a zirconium dynamic membrane. Proc. Biochem., 35, 377-383.

Zaborsky, O. R. (1973), Entrapment within crosslinked polymers. In: Immobilized enzymes. CRC Press. pp. 83-91.

Zanin, G. M.; Kambara, L. M.; Calsavara, L. P. V. and De Moraes, F. F. (1994), Performance of fixed and fluidized bed reactors with immobilized enzyme. Appl.Biochem. Biotechnol., 45/46, 627-640.

Received: February 20, 2001; Revised: July 08, 2001; Accepted: April 04, 2002. 